\title{
The study of natural essential oils as growth regulators of winter wheat
}

\author{
Ludmila Dyadiuchenko ${ }^{1 *}$, Victor Taranenko ${ }^{1}$, Vyacheslav Muraviev ${ }^{1,2}$, and Irina \\ Dmitrieva $^{3}$ \\ ${ }^{1}$ Federal State Budgetary Scientific Institution"All-Russian Research Institute of Biological Plant \\ Protection", Krasnodar-39, Krasnodar, 350039, Russia \\ ${ }^{2}$ Kuban State University, 149 Stavropolskaya st., Krasnodar, 350040, Russia \\ ${ }^{3}$ I.T. Trubilin Kuban State Agrarian University, 13 Kalinina st., Krasnodar, 350044, Russia
}

\begin{abstract}
Growth regulators are rather important for obtaining high yields of agricultural crops. Recently, more and more research on biologically active substances has been carried out among natural products, in particular, essential oils of plants. Our study is aimed at the search for winter wheat growth regulators among essential oils. In three-year field small-plot experiments, the growth-regulating activity of anise, fenchel and apricot oils was studied. When we treated the vegetating plants with the water emulsions of the above mentioned oils (dose - $30 \mathrm{~g} / \mathrm{ha}$ ) twice in the tillering and the flag leaf phases, the yield increase of Grom winter wheat variety was $8.6-10.8 \%$. The quality of seeds also improved: the protein content increased by $0.6-1.1 \%$, gluten by $1.8-2.7 \%$.
\end{abstract}

\section{Introduction}

Winter wheat in the Russian Federation, as well as throughout the world, is an economically important agricultural crop, which makes it the object for developing new technologies.

High-quality grain is always, and especially recently, in high demand. That is why the search for opportunities to increase winter wheat yield is of great importance. In modern agriculture, plant growth regulators are widely used for this purpose [1]: chemicals of synthetic or natural origin that affect the biological and biochemical development of plants and allow you to manage necessary plant growth.

At the same time, the problem of the pesticidal press on the environment is becoming ever more acute. Xenobiotics contaminate the soil, water, food, cause harm to human health, animals [2-3]. In this regard, scientific research has shifted towards the use of natural products that are highly active and environmentally friendly. In this regard, scientific research has shifted towards the use of natural products that are highly active and environmentally friendly.

\footnotetext{
*Correponding author: ludm.dyadiuchenko@yandex.ru
} 
Therefore, essential oils are a "green" pantry containing numerous biologically active substances with various effects both on humans and plants. They include products with therapeutic properties exhibitting antimicrobial and antibacterial [4], antifungal [5], anticancer [6], immunomodulating [7] activities. They can be used as food additives and antioxidants in food production [8-9]. More and more new substances with insecticidal [1011], fungicidal [12-13], acaricidal [14] effects are discovered. Regarding the effect of essential oils on plant growth and development, inhibitors of the germination of potato tubers during storage [15] and substances with a herbicidal effect on weeds [16] were found. Essential oils with growth-stimulating effect are also known, however, there are only a few publications on this topic [17-18], therefore, additional studies in this area are relevant and important.

The research is aimed at the search for winter wheat growth regulators among natural essential oils.

\section{Materials and methods}

In the experiment we used pharmaceutic essential oils (Interstate standard 31791-2012).

Small-plot field experiments were carried out in 2016-2018 on the experimental field of the All-Russian Research Institute of Biological Plant Protection (Krasnodar) under the conditions of permanent crop rotation. The climate is moderately continental with mild winters and hot summers. The average annual air temperature is $+10.0-11.0{ }^{\circ} \mathrm{C}$, the average annual rainfall is $610-650 \mathrm{~mm}$; precipitation is not evenly distributed over the months.

Meteorological conditions for sowing winter wheat in the autumn period in terms of temperature and humidity were quite favorable. During the winter dormancy period (December - February), the snow cover was short-term and unstable, the spring period of 2018 was dry, in contrast to previous years.

The soil of the plot is leached chernozem, powerful, heavy loam. The humus content in the arable layer is about $4.0 \%$. The upper layer has a neutral and slightly acidic reaction ( $\mathrm{pH}$ of the aqueous extract 6.7-7.0). The content of mobile forms of phosphorus is $17.4 \mathrm{mg} / 100 \mathrm{~g}$ of soil, potassium $-32.8 \mathrm{mg} / 100 \mathrm{~g}$ of soil.

In the field experiments we used Grom winter wheat variety. The variety is semi-dwarf, resistant to lodging and shedding, mid-season, characterized by high productivity, refers to valuable wheat varieties.

To determine the growth-regulating effect we applied aqueous emulsions of the studied essential oils on the vegetative wheat plants. To prepare the emulsions we used an emulsifier in an amount of $0.01 \%$ of the solvent weight. The crops were treated by spraying twice: in the tillering phase (dose of $30 \mathrm{~g} / \mathrm{ha}$ ) and in the phase of the flag leaf (dose of $30 \mathrm{~g} / \mathrm{ha}$ ). The preparation Bigus, BP, based on the natural humic acids (the preparative form is an aqueous solution, the active substance is potassium salts of humic acids, a concentration of $25 \mathrm{~g} / \mathrm{l}$ by the acid) was chosen as a reference standard. The application of the standard was carried out in the same doses and at the same time. Plants of the control option were not treated.

The check area of a plot was $6 \mathrm{~m}^{2}$, there were four replications, the location of the plots was randomized.

To study the effect of the growth regulators on plant growth and development, the experiment involved the measurement of biometric indicators, as well as the measurement of the organs that form the crop structure and yield. Grain quality was determined by the content of protein, gluten and starch.

To assess photosynthetic activity, the content of pigments in the leaves of the plants was determined. The first sampling was performed 1 day after the first treatment with the growth regulator, then every 12 days until the harvest. The content of chlorophylls and 
carotenoids was measured on a Genesys 8 spectrophotometer (Thermo Spectronic, England) in extracts with $96 \%$ ethanol and subsequent calculation using the Lichtentaller formulas [19]. There were three analytical replications.

Analysis of the quality indicators of the yield was carried out using a NIR analyzer "Infralum 2007" three times.

Mathematical processing of all experimental data was carried out using the program Statistica 13.3.

\section{Results and discussion}

For the further field tests we selected three products by laboratory testing: anise oil, fenchel oil and apricot oil.

According to the results of three-year field studies, the essential oils of anise, fenchel and apricot showed the properties of growth regulators. Table 1 shows the average data obtained over three years concerning the influence of the studied substances on the yield and quality of grain of winter wheat.

Table 1. The effect of the growth regulators on productivity and grain quality of Grom winter wheat variety

\begin{tabular}{|c|c|c|c|c|c|c|}
\hline \multirow{2}{*}{$\begin{array}{l}\text { Experiment } \\
\text { al option }\end{array}$} & \multirow{2}{*}{$\begin{array}{l}\text { Yield, } \\
\text { dt/ha }\end{array}$} & \multicolumn{2}{|c|}{ Increase in control } & \multicolumn{3}{|c|}{ Grain content of , $\%$} \\
\hline & & $\mathrm{dt} / \mathrm{ha}$ & $\%$ & protein & gluten & starch \\
\hline anise oil & 61.8 & 6.0 & 10.8 & 16.8 & 22.4 & 69.9 \\
\hline fenchel oil & 60.6 & 4.8 & 8.6 & 16.5 & 22.8 & 68.0 \\
\hline apricot oil & 60.9 & 5.1 & 9.1 & 16.3 & 21.9 & 70.7 \\
\hline $\begin{array}{l}\text { Bigus, BP } \\
\text { (standard) }\end{array}$ & 59.9 & 4.1 & 7.3 & 16.5 & 22.0 & 69.8 \\
\hline control & 55.8 & - & - & 15.7 & 20.1 & 65.7 \\
\hline $\mathrm{HCP}_{05}$ & 2.65 & - & - & 0.91 & 0.80 & 2.15 \\
\hline
\end{tabular}

The results of the study indicate that the use of anise oil as a growth regulator made it possible to obtain an increase in the yield of winter wheat on average about $6.0 \mathrm{dt} / \mathrm{ha}$, the use of fenchel oil increases the yield by $4.8 \mathrm{dt} / \mathrm{ha}$, and apricot oil by $5.1 \mathrm{dt} / \mathrm{ha}$, which is $10.8 \%$, $8.6 \%$ and $9.1 \%$, respectively, comparing to the control option (Table 1 ). It should be noted that crop yields varied over years. So, a higher yield was noted in 2017, the most favorable in weather conditions. In 2017, the yield on the control plot amounted to $60.0 \mathrm{dt} / \mathrm{ha}$, and on the plot with the application of anise oil - $67.2 \mathrm{dt} / \mathrm{ha}$, that is, the growth-regulating effect was $12.0 \%$. The lowest yield was recorded in dry 2018 . The growth-regulating activity of the Bigus, BP preparation was a bit lower than the one of the experimental options, and amounted up to $7.3 \%$.

Moreover, the use of essential oils improved grain quality, the protein content in seeds increased by $0.6-1.1 \%$ compared with the control, and the gluten content increased by 1.8 $2.7 \%$.

Table 2 shows the average data over a three-year period on the effect of the studied essential oils on the development of organs that form the crop.

The field experiments revealed that in plants treated with the essential oils, the number of productive stems increased by 5.6-8.5 \%, the height of plants increased by 4-7 cm, the color of plants had a more intense green color compared to the control. A similar picture was observed when using the Bigus, BP standard. A positive effect of growth regulators was also noted in the size of the spike, its length increased by 5.3-8.4\%, the number of spikelets per ear was 5.9-11.4\% higher, and the number of grains per ear was $1.7-5.4 \%$ 
higher compared to the untreated plants. The grain weight per ear exceeded the control option by 3.9-11.6\%, and the mass of 1000 grains - by 3.5-4.0\%, i.e. in plants treated with the growth regulators, there were more grains in an ear and they were larger (Table 2).

Table 2. The effect of the growth regulators on the structure of the crop of Grom winter wheat variety

\begin{tabular}{|c|c|c|c|c|c|c|}
\hline $\begin{array}{c}\text { Experiment } \\
\text { al option }\end{array}$ & $\begin{array}{c}\text { Plant } \\
\text { density, } \\
\text { pcs } / \mathrm{m}^{2}\end{array}$ & $\begin{array}{c}\text { Spike } \\
\text { length, mm }\end{array}$ & $\begin{array}{c}\text { Number of } \\
\text { spikelets per } \\
\text { ear, pcs. }\end{array}$ & $\begin{array}{c}\text { Number of } \\
\text { grains per } \\
\text { ear, pcs. }\end{array}$ & $\begin{array}{c}\text { Grain } \\
\text { weight } \\
\text { per ear, g }\end{array}$ & $\begin{array}{c}\text { The mass of } \\
1000 \text { grains, } \\
\text { g }\end{array}$ \\
\hline anise oil & 522 & 102 & 28.3 & 42.8 & 2.02 & 42.3 \\
\hline $\begin{array}{c}\text { fenchel } \\
\text { oil }\end{array}$ & 508 & 99 & 26.9 & 41.9 & 1.88 & 41.8 \\
\hline apricot oil & 516 & 99 & 27.1 & 41.2 & 1.88 & 42.0 \\
\hline $\begin{array}{c}\text { Bigus, BP } \\
\text { (standard) }\end{array}$ & 499 & 98 & 27.0 & 41.0 & 1.90 & 41.8 \\
\hline control & 481 & 94 & 25.4 & 40.6 & 1.81 & 40.4 \\
\hline $\mathrm{HCP}_{05}$ & 18.70 & 4.0 & 1.44 & 0.61 & 0.10 & 1.38 \\
\hline
\end{tabular}

At the same time, the use of the growth regulators stimulated the photosynthetic activity of the winter wheat plants. They effected the increse in both the total content of photosynthetic pigments in wheat leaves (Fig. 1), and the content of individual pigments: chlorophyll $a$, chlorophyll $b$ and carotenoids.

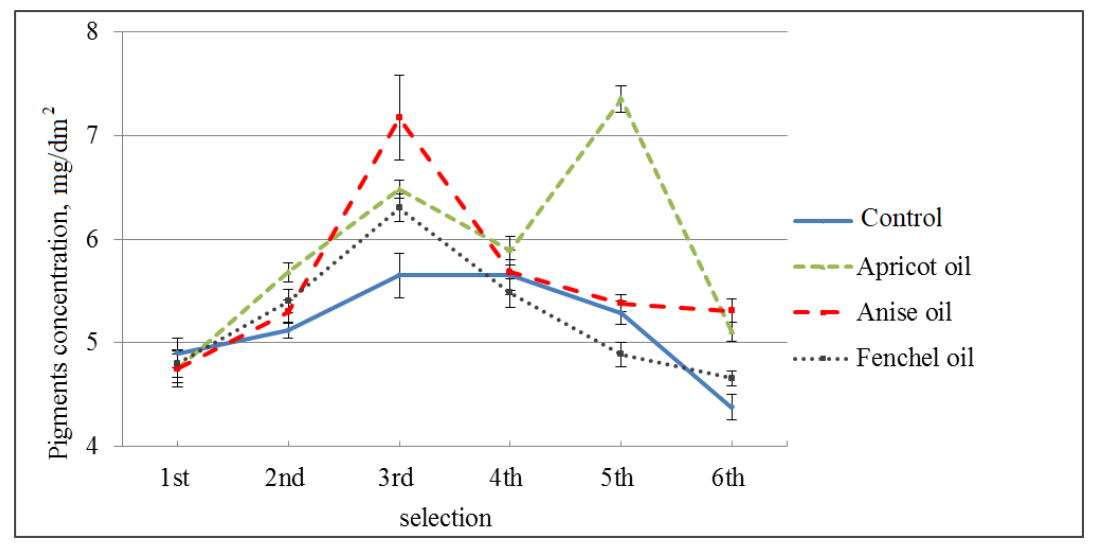

Fig. 1. Dynamics of the total content of photosynthetic pigments in the leaves of Grom winter wheat variety during the period from the tillering phase to harvest, $\mathrm{mg} / \mathrm{dm}^{2}$ (2018)

Some publications reveal the key role of chlorophyll $b$ in the regulation of plant development [20]. In our case, the use of the essential oils led to a sharp increase in the content of chlorophyll $b$ in the wheat leaves after the second treatment in the phase of the flag leaf (Fig. 2). The essential oils also effected positively the content of chlorophyll $a$. 


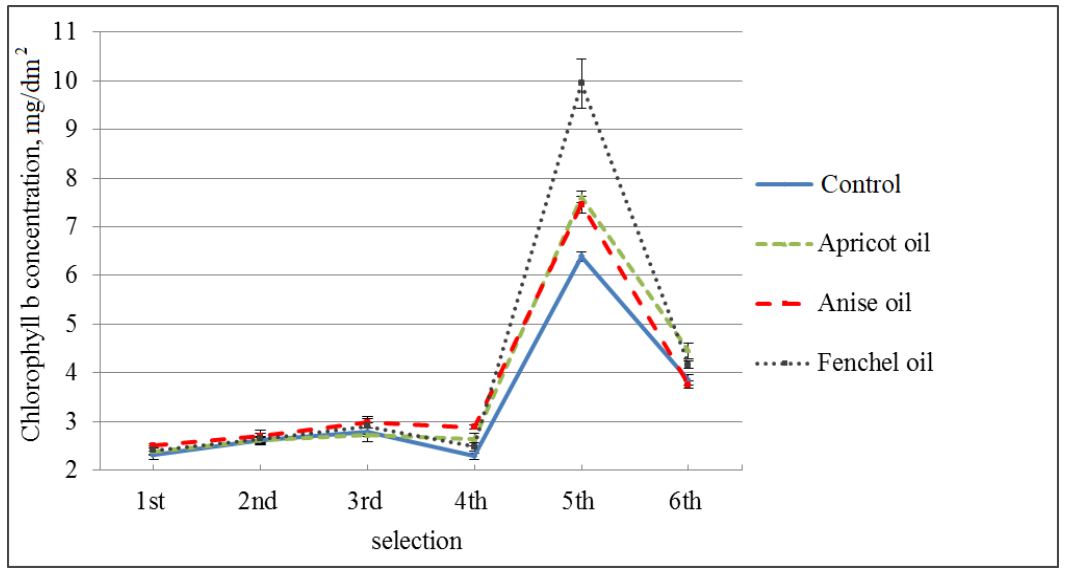

Fig. 2. Dynamics of chlorophyll $b$ content in the leaves of Grom winter wheat variety from the tillering phase to harvest, $\mathrm{mg} / \mathrm{dm}^{2}$ (2018)

Thus, the use of anise, fenchel and apricot oils as growth regulators on winter wheat vegetative plants significantly increases the crop yield, improves grain quality, and activates photosynthetic activity of plants.

This research proves that essential oils can be considered as an alternative to synthetic products when looking for promising, environmentally friendly plant growth regulators. The essential oils of anise, fenchel and apricot can be used as natural growth regulators of winter wheat.

The study was performed in accordance with the State Assignment 075-00376-19-00 of the Russian Ministry of Education and Science, the research project 0686-2019-0013.

\section{References}

1. L.G. Nickell, Plant. Growth Regulating Chemicals (CRC Press, 2018). https://doi.org/10.1201/9781351075749

2. I. Buchanan, H.C. Liang, V. Razaviarani, Water Environ. Res., 84, 1533 (2012) https://doi.org/10.2175/106143012X13407275695436

3. N. Gonzalez, M. Margues, M. Nadal, J.L. Domingo, Food \& Chem. Tox., 125, 370 (2019) https://doi.org/10.1016/j.fct.2019.01.021

4. A. Ludwiczuk, A. Kieltyka-Dadasiewicz, R. Sawicki, J. Golus, G. Ginalska, Nat. Prod. Com., 11, 1015 (2016) https://doi.org/10.1177/1934578X1601100736

5. M. Stupar, M.L. Grbič, M.L. Džamič, (...), M. Ristič, J. Vukojivič, Archives Biologic. Sci., 66, 1539 (2014) https://doi.org/10.2298/ABS1404539S

6. M. Taherkhani, J. Essetial Oil - Bearing PlantsMed., 18, 1329 (2015) https://doi.org/10.1080/0972060X.2014.1000388

7. I.E. Orhan, M.A. Mesaik, A. Jabeen, Y. Kan, Ind. Crops \& Prod., 81, 117 (2016) https://doi.org/10.1016/j.indcrop.2015.11.088

8. I.C. de Jesus, G.G. Santos Frazao, A.F. Blank, L.C.L. de Aguino Santana, Microbial Pathogen., 99, 142 (2016) https://doi.org/10.1016/j.micpath.2016.08.023

9. M. Paterio, F.J. Barba, R Dominques, (...), B. Gomez, J.M. Lorenzo, Food Res. Int.,. 113, 156 (2018) https://doi.org/10.1016/j.foodres.2018.07.014

10. F. Titouhi, M. Amri, C. Messaoud, S. Haouuel, S. Youssfi, A. Cherif, FJ.M.B. Jemaa, J. Stored Prod. Res. 72, 11 (2017) https://doi.org/10,1016/jspr.2017.02.07

11. V. Sergeeva, Acta Hortickult., 1125, 361 https://doi.org/10.17660/ActaHortic.2016.1125.47 
12. C. Pedrotti, R.T.D. Silva Riberio, J. Schwambach, Crop Prot., 125, 104912 (2019) https://doi.org/10.1016/j.cropro.2019.104912

13. J. Amini, V. Farhang, T. Javadi, J. Nazemi, Plant Pathol. J., 32, 16 (2016) https://doi.org/10.5423/PPJ.OA.05.2015.0091

14. N.C. Ribero, C.A.G. da Camara, J.P.R. Melo, M.M. de Moraes, J. App. Entom., 143, 731 (2019) https://doi.org/10.1111/jen.12642

15. S. Shukla, S.S. Pandey, M. Chandra, (...), M.P. Darokar, A. Karla, Food Chem., 284, 171 (2019) https://doi.org/10.1016/j.foodchem.2019.01.079

16. E.S.C. Gurgel, V.S. de Oliveira, (...), M.C. de Mendoca, A.P.D.S. Souza Filho, Ind. Crohs \& Prod., 142, 111850 (2019) https://doi.org/10.1016/j.indcrop.2019.111850

17. A.M.P. Jones, M.R. Shukla, S.M. Sherif, P.B. Brown, P.K. Saxena, Plant Cell Rep., 35, 91 (2016) https://doi.org/10.1007/s00299-015-1870-1

18. E.V. Kalyuta, M.I.Maltsev, O.V. Shepeleva, E.V. Isayeva, Khimiya Rastitel'nogo Syr'ya, 4, 203 (2017) https://doi.org/10.14258/jcprm.2017041765

19. H. K. Lichtentaller, A. R. Wellburn, Biochem. Soc. Trans. 11, 591 (1983)

20. V.Tyutereva, V.A. Dmitrieva, O.V. Voitsekhovskaja, Selskokhosyastvennaya biologia, 52, 843 (2017) https://doi.org/10.15389/agrobiology.2017.5.843eng 